\title{
Menstrual hygiene practice between rural and urban high school adolescent girls in Bangladesh
}

\author{
Rajea Sultana $^{1 *}$, Ela Rani Shom ${ }^{2}$, Fahima Khatun ${ }^{2}$
}

\begin{abstract}
${ }^{1}$ Senior Staff Nurse, Dhaka Medical College Hospital, Dhaka, Bangladesh
${ }^{2}$ Faculty of Women's Health Nursing and Midwifery, National Institute of Advanced Nursing Education and Research, Mugda, Dhaka, Bangladesh
\end{abstract}

Received: 30 November 2019

Revised: 27 December 2019

Accepted: 03 January 2020

\author{
*Correspondence: \\ Dr. Rajea Sultana, \\ E-mail: sultana.rajea@yahoo.com
}

Copyright: (C) the author(s), publisher and licensee Medip Academy. This is an open-access article distributed under the terms of the Creative Commons Attribution Non-Commercial License, which permits unrestricted non-commercial use, distribution, and reproduction in any medium, provided the original work is properly cited.

\begin{abstract}
Background: Menstruation is a natural, normal biological process experienced by all adolescent girls and women. Urinary tract infection, reproductive tract infection and complication during pregnancy are the impact of poor menstrual hygiene practices. The aim of this study is to compare the menstrual hygiene practice between rural and urban high school adolescent girls in Bangladesh.

Methods: A descriptive comparative study design was used. Cluster sampling technique was used to select 120 study participants. The data were collected through self-reported questionnaire by structured questionnaires. In descriptive statistics; frequency, percentage, mean, standard deviation and in inferential statistics; chi-square-test, t-test was used to compare the menstrual hygiene practice between rural and urban. Data was analyzed using SPSS version 23.

Results: There was significant difference between rural and urban girls regarding mean age at menarche $(5.50, \mathrm{p}=$ 0.000). There was a statistically significant difference between rural and urban girls using of sanitary pad $(30.54, \mathrm{p}=$ $0.000)$ and reusable cloth $(38.92, \mathrm{p}=0.000)$.

Conclusions: This study found that menstrual hygiene practice (MHP) was more among the urban high school adolescent girls than in the rural high school adolescent girls. The result provides baseline information regarding menstrual hygiene practice (MHP) among rural participants that's why need more emphasize on health promotion and counseling program regarding menstrual hygiene practice (MHP) among rural and primary level health sectors in Bangladesh.
\end{abstract}

Keywords: Adolescent girls, High school, Hygiene practice, Menstruation

\section{INTRODUCTION}

Menstruation is a natural and biological process experienced by all adolescent girls and women. ${ }^{1}$ The onset of menstruation is one of the most important changes occurring in girls during adolescent years. In the developing countries average age of menarche 12-13 years and in urban areas menarche was 12.5 years and more earlier. ${ }^{2}$ Hygienic practices during menstruation are the use of sanitary pads and adequate washing of genital area. $^{3}$ Good menstrual hygiene practices (MHP) are essential during menstruation; they include 1) regular change of clothing and underwear; 2) change of hygienic pads every three to four hours; 3) daily showering, 4) adequate washing of genitalia after each voiding of urine and feces. ${ }^{4}$

In Iran near half of the girls are unaware about menstruation and hygiene practice. ${ }^{5}$ In India, there are some 113 million adolescent girls who are vulnerable at the onset of menarche and face significant barriers to a 
comfortable and dignified experience with MHP, 1 and one out of 164 girls used sanitary pads and 10 percent of girls are unaware about menstruation. ${ }^{6}$ In South Asia 1 out of 3 girls are vulnerable at MHP. ${ }^{5}$ In Bangladesh, ninety percent girls in the rural area used old cloths and stored their menstrual cloth in a hidden place. ${ }^{7}$

Reproductive and sexual ill health with its complications is the burden for women. Urinary tract infection, abdominal pain, scabies in the vaginal area, absence from school, and complication during pregnancy are the impact of poor MHP. ${ }^{8,9}$ Near half of the students are in the lower level of practice for the uncomfortable school environment. ${ }^{3}$ MHP is an important issue affecting the health, dignity, self-esteem and privacy of millions of adolescent girls and women across the globe. There was a huge gap exists in MHP between rural and urban adolescent girls. ${ }^{1}$ In addition there was not found any comparative study between rural and urban MHP in Bangladesh.

Thus, the investigator would like to compare the MHP between urban and rural adolescent girls in Bangladesh. This study will serve an important purpose for contextualizing the current MHP of adolescent girls. The findings of the study will provide important information for the women's health nurse, school health nurse, and public health nurse to conduct a health education program in schools and community that can improve MHP of adolescent girls.

\section{METHODS}

The descriptive comparative study design was used. The study was carried out between July 2018 to June 2019. Syedpur Keramotia B. L. High School, Pirgacha, Rangpur was selected for data collection among rural adolescent girls, and Barnamala Ideal School and College, Jatrabari, Dhaka was selected for data collection among urban adolescent girls. Cluster sampling technique was used to select study participants. Power analysis was used to estimate the number of the subject of the study.

The estimated sample size was calculated for an acceptable minimum level of significant alpha $(\alpha)$ of 0.05 , an expected power of 0.801 -beta (" $1 \beta$ ", the power of the test), and an estimated population effect size of gamma $0.25(\gamma)$ as the medium effect size used in the nursing studies. According to power analysis, the estimated sample size was 120 . In addition, $12 \%$ attrition rate included to the estimated sample size. Adolescent girls who met the inclusion criteria, and present in the school during study period were recruited in the study.

\section{Inclusion criteria}

- Girls who were study in class eight to ten

- Those were physically and mentally fit.

\section{Exclusion criteria}

- Girls those were irregular menstrual cycle

- Girls those were married.

The investigator modified the questionnaire based on literature review in context of Bangladesh. Semistructured and pre-validated questionnaire of Menstrual Hygiene Management were used. ${ }^{10}$ The instruments were constructed of two parts. Part I: Socio-demographic questionnaire: this part consisting of 13 items including age, religion, class of study, weight, height, mothers' educational level, fathers' educational level, family members, type of family, monthly family income, type of house, place of defecation, and source of drinking water. Part II: this part consisting of 13 items related to menstrual hygiene practice (MHP). The questionnaires were validated by panel of three experts of NIANER. The reliability of the instruments: Cronbach's Alpha was 0.47 .

The study was approved by Institutional Review Board (IRB) of the National Institute of Advanced Nursing Education and Research (NIANER) and Bangabandhu Sheikh Mujib Medical University (BSMMU). IRB No: Exp.NIA-S-2018-13. Data collection was started after obtaining permission from the head teacher and class teacher of the school. The purpose of the study was explained to the participants, and written consent was obtained from them. Data was collected by structured self-reporting questionnaire. Questionnaire provided to them and they took about 30 minutes to complete the questionnaire.

\section{Statistical analysis}

Data were analyzed by using SPSS version 23 . Descriptive and inferential statistics was used. In descriptive statistics; frequency, percentage, mean and standard deviation was used to describe the demographic characteristics, menstrual characteristics and menstrual hygiene practice of rural and urban. In inferential statistics; chi-square-test, t-test was used to compare the menstrual characteristics and MHP between rural and urban. A value of $\mathrm{p} \leq 0.05$ was considered statistically significant.

\section{RESULTS}

The total subject consisted of 120 high school adolescent girls, $50 \%$ from rural and another $50 \%$ from urban participated in this study. The mean age of participants in rural school was $14.58 \pm 0.94$ and urban school was $14.08 \pm 0.93$ years.

The majority (87.5\%) of rural participants' mothers' educations were primary and below and in urban majority $(75 \%)$ of the mothers' education were secondary and above. The majority $(91.7 \%)$ of rural participants' fathers' education were primary and below whereas in 
urban majority $(77.8 \%)$ were secondary and above. The Near about fifty percent $(44.4 \%)$ of rural and more than fifty five percent $(55.6 \%)$ of urban participants lived in nuclear family. The mean score of family income in rural was $11891.67 \pm 6735.36 \mathrm{BDT}$, whereas in urban is 43716.67 \pm 31286.0 BDT.
Among total participants, near about fifty percent (46.9\%) of rural and more than fifty percent $(53.1 \%)$ of urban participants used house toilet for defecation. The most $(93.7 \%)$ of the rural girl's drunk tube well water whereas most $(98.2 \%)$ of the urban girls drunk tap water (Table 1).

Table 1: Distribution of socio demographic characteristics of rural and urban participants $(\mathbf{N}=120)$.

\begin{tabular}{|c|c|c|c|c|c|}
\hline \multirow{2}{*}{ Items } & \multirow{2}{*}{ Categories } & \multicolumn{2}{|c|}{ Rural $(n=60)$} & \multicolumn{2}{|c|}{ Urban $(n=60)$} \\
\hline & & n $(\%)$ & Mean \pm SD & n $(\%)$ & Mean \pm SD \\
\hline Age & & & $14.58 \pm 0.944$ & & $14.08 \pm 0.926$ \\
\hline \multirow{2}{*}{ Religion } & Islam & $59(50.0)$ & & $59(50.0)$ & \\
\hline & Hindu & $1(50.0)$ & & $1(50.0)$ & \\
\hline \multirow{3}{*}{ Class of study } & Class eight & $31(60.8)$ & & $20(39.2)$ & \\
\hline & Class nine & $10(31.3)$ & & $22(68.8)$ & \\
\hline & Class ten & $19(51.4)$ & & $18(48.6)$ & \\
\hline BMI & & & $17.60 \pm 2.9$ & & $18.79 \pm 3.03$ \\
\hline \multirow{2}{*}{ Mothers' education } & Primary and below & $42(87.5)$ & & $6(12.5)$ & \\
\hline & Secondary and above & $18(25)$ & & $54(75)$ & \\
\hline \multirow{2}{*}{ Fathers' education } & Primary and below & $44(91.7)$ & & $4(8.3)$ & \\
\hline & Secondary and above & $16(22.2)$ & & $56(77.8)$ & \\
\hline \multirow{2}{*}{ Type of family } & Nuclear family & $44(44.4)$ & & $55(55.6)$ & \\
\hline & Joint family & $16(76.2)$ & & $5(23.8)$ & \\
\hline Family members & & & $4.68 \pm 1.097$ & & $5.00 \pm 1.974$ \\
\hline Monthly income & & & $11891.67 \pm 6735.36$ & & $43716.67 \pm 31286.04$ \\
\hline \multirow{2}{*}{ Place of defecation } & Open space & $7(100)$ & & 0 & \\
\hline & House toilet & $53(46.9)$ & & $60(53.1)$ & \\
\hline \multirow{2}{*}{ Drinking water } & Tube well & $59(93.7)$ & & $4(6.3)$ & \\
\hline & Tap & $1(1.8)$ & & $56(98.2)$ & \\
\hline
\end{tabular}

Table 2: Menstrual characteristics of rural and urban participants $(\mathrm{N}=120)$.

\begin{tabular}{|c|c|c|c|c|c|}
\hline \multirow{2}{*}{ Items } & \multirow{2}{*}{\multicolumn{2}{|c|}{ Categories }} & \multirow{2}{*}{$\begin{array}{l}\text { Rural }(n=60) \\
\text { n } \%\end{array}$} & \multicolumn{2}{|l|}{$\operatorname{Urban}(n=60)$} \\
\hline & & & & n \% & $\mathbf{x}^{2 / t(\mathbf{P})}$ \\
\hline Mean & & & $12.67 \pm 0.795$ & $11.82 \pm 0.892$ & $5.50(0.000)$ \\
\hline \multirow{2}{*}{\multicolumn{2}{|c|}{ Regular interval }} & Yes & $47(49.5)$ & $48(50.5)$ & \\
\hline & & No & $13(52)$ & $12(48)$ & \\
\hline \multirow{2}{*}{\multicolumn{2}{|c|}{ Type of flow }} & Normal flow & $37(42.5)$ & $50(57.5)$ & \multirow{2}{*}{$7.06(0.008)$} \\
\hline & & Abnormal flow & $23(69.7)$ & $10(30.3)$ & \\
\hline \multirow{4}{*}{\multicolumn{2}{|c|}{$\begin{array}{l}\text { Discomfort during menstruation } \\
\text { (multiple response) }\end{array}$}} & $\begin{array}{l}\text { Pain in lower } \\
\text { abdomen }\end{array}$ & $44(55.7)$ & $35(44.3)$ & \\
\hline & & Backache & $12(32.4)$ & $25(67.6)$ & $8.33(0.015)$ \\
\hline & & Weakness & $9(40.9)$ & $13(59.1)$ & \\
\hline & & Others discomfort & & $4(100)$ & \\
\hline \multirow{3}{*}{\multicolumn{2}{|c|}{ Consult for menstrual problems }} & Parents & $38(47.5)$ & $42(52.5)$ & \\
\hline & & With others & $15(55.6)$ & $12(44.4)$ & \\
\hline & & Don't consult & $7(53.8)$ & $6(46.2)$ & \\
\hline
\end{tabular}

The mean age of menarche among rural girls was $12.67 \pm 0.795$ years and urban girls were $11.82 \pm 0.892$ years. There was significant difference between rural and urban regarding mean age of menarche $(\mathrm{t}=5.50, \mathrm{p}=$ $0.000)$. Seventy percent $(69.7 \%)$ of rural girls and $30.3 \%$ of urban girls had abnormal flow of menstruation. There was a significant difference between rural and urban participants about flow of menstruation $\left(\mathrm{x}^{2}=7.06, \mathrm{p}=\right.$ 0.008). Near about seventy percent $(67.6 \%)$ of urban girls and in rural only $32.4 \%$ of girls were feeling backache during menstruation. There was significant difference 
between rural and urban regarding discomforts of backache $\left(\mathrm{x}^{2}=8.33 \mathrm{p}=0.015\right)$ (Table 2).

The majority $(81.5 \%)$ of rural girls and only $18.5 \%$ of urban girls used reusable cloth. There was significant difference between rural and urban about use of reusable cloth $\left(\mathrm{x}^{2}=38.92, \mathrm{p}=0.000\right)$. The majority $(72.1 \%)$ of urban girls and only twenty eight percent $(27.9 \%)$ of rural girls used sanitary pad. There was significant difference between rural and urban about use of sanitary pad $\left(\mathrm{x}^{2}=\right.$ $30.54, \mathrm{p}=0.000)$. The majority $(85.7 \%)$ of urban girls used tissue paper and only forty percent $(14.3 \%)$ of rural girls used tissue paper. The participants in both groups who were used reusable cloth; all of them washed cloth with water and soap. The majority (76.9\%) of rural girls and $23.1 \%$ of urban girls dried reusable cloth in the open space under the sunlight. The majority $(88.6 \%)$ of rural girls dispose absorbent in toilet and the majority (82.1\%) of urban girls dispose absorbent in dustbin. Statistically significant difference between rural and urban disposal methods of sanitary absorbent $\left(x^{2}=62.64, p=0.000\right)$. The less than fifty percent $(43.8 \%)$ of rural girls and more than fifty percent $(56.2 \%)$ of urban girls change absorbent twice or thrice daily. There was significant difference between rural and urban frequency of change of absorbent $\left(\mathrm{x}^{2}=5.26, \mathrm{p}=0.022\right)$ (Table 3$)$.

Table 3: Comparison of menstrual hygiene practices between rural and urban participants $(\mathbf{N}=120)$.

\begin{tabular}{|c|c|c|c|c|}
\hline \multirow{2}{*}{ Items } & \multirow{2}{*}{ Categories } & \multirow{2}{*}{$\begin{array}{l}\text { Rural }(n=60) \\
n(\%)\end{array}$} & \multicolumn{2}{|l|}{ Urban $(n=6)$} \\
\hline & & & n $(\%)$ & $\mathbf{x}^{2}(\mathbf{P})$ \\
\hline \multirow{2}{*}{$\begin{array}{l}\text { Daily bath during } \\
\text { menstruation }\end{array}$} & Yes & $56(50)$ & $56(50)$ & \\
\hline & No & $4(50)$ & $4(50)$ & \\
\hline \multirow{2}{*}{$\begin{array}{l}\text { Washing private parts } \\
\text { daily }\end{array}$} & With water only & $22(52.4)$ & $20(47.6)$ & \\
\hline & With water and soap & $38(48.7)$ & $40(51.3)$ & \\
\hline \multirow{4}{*}{$\begin{array}{l}\text { Type of absorbent } \\
\text { used (multiple response) }\end{array}$} & Reusable cloth & $44(81.5)$ & $10(18.5)$ & $38.92(0.000)$ \\
\hline & Sanitary pad & $19(27.9)$ & $49(72.1)$ & $30.54(0.000)$ \\
\hline & One-time cloth & $5(50)$ & $5(50)$ & \\
\hline & Tissue paper & $1(14.3)$ & $6(85.7)$ & $3.79(0.051)$ \\
\hline $\begin{array}{l}\text { Washing reusable } \\
\text { cloth }\end{array}$ & Wash with water and soap both & $44(81.5)$ & $10(18.5)$ & $38.92(0.000)$ \\
\hline \multirow{2}{*}{ Drying reusable cloth } & At home in dark space & $34(82.9)$ & $7(17.1)$ & \\
\hline & In the open space under the sunlight & $10(76.9)$ & $3(23.1)$ & \\
\hline \multirow{3}{*}{$\begin{array}{l}\text { Disposal methods } \\
\text { of sanitary absorbent }\end{array}$} & Dustbin & $12(17.9)$ & $55(82.1)$ & \multirow{3}{*}{$62.64(0.000)$} \\
\hline & Toilet & $31(88.6)$ & $4(11.4)$ & \\
\hline & Others & $17(94.4)$ & $1(5.6)$ & \\
\hline \multirow{2}{*}{$\begin{array}{l}\text { Frequency of } \\
\text { change of absorbent }\end{array}$} & Twice or thrice daily & $39(43.8)$ & $50(56.2)$ & \multirow[t]{2}{*}{$5.26(0.022)$} \\
\hline & Once a day & $21(67.7)$ & $10(32.3)$ & \\
\hline
\end{tabular}

\section{DISCUSSION}

In this study mean age of participants were $14.58 \pm 0.944$ years among rural and 14.08 \pm 0.926 years among urban girls. Similarly, previous studies found that participants were adolescent groups..$^{1,11,12}$ In this study the majority of the rural participants' mothers had primary level education and in urban more than fifty percent had secondary level education. In consistently previous study found that more than fifty percent of the participants mothers were illiterate in rural and near about fifty percent among urban were secondary level education. ${ }^{13}$ Another study found that more than fifty percent girls' mothers were illiterate in rural and in urban majority were literate. ${ }^{14}$

The previous study found that whose mother had higher level of education they had higher level of hygiene practice. $^{3}$
The majority of girls in rural and most of the girls in urban lived in nuclear family. In contrast previous study found that more than fifty percent in both groups lived in joint family. ${ }^{13}$ The mean of family members were $4.68 \pm 1.09$ in rural and $5.0 \pm 1.97$ in urban. Previous studies found that the mean of family members in rural were 7.44 and in urban were 7.38.13. ${ }^{10}$ The present study found that the mean age of menarche in rural participants were $12.67 \pm 0.795$ years, and in urban participants were $11.82 \pm 0.892$ years. Similarly, another study found that mean age of menarche was $11.9 \pm 0.9$ years. ${ }^{15}$ In Belgaum the mean age of menarche was $12.8 \pm 1.73$ and South Africa was 13 years. ${ }^{16,17}$

In present study, found that the majority of girls in both groups were regular interval in menstruation. Consistently another study found that participants had regular interval of menstruation. ${ }^{1}$ In this study the majority of girls had dysmenorrhea among rural and 
urban participants respectively. One study found similar result among Bangladeshi rural girls about experienced of dysmenorrhea. ${ }^{8}$ In present study parents were the main source of information, and consultation about menstruation among both rural and urban girls. Participants specified that especially mothers were the main source of information. Several studies found that the similar results. ${ }^{1,11,13,14,18}$

In present study found that most of the participants took daily bath during menstruation in both groups. Previous studies found the similar results. ${ }^{10,13}$ More than fifty percent of rural and urban girls wash their private parts with water and soap both. The Similarly previous study found that the girls washed their private parts with water and soap both. ${ }^{13}$ In contrast previous study found that majority of the girls wash with water and only twenty seven percent girls wash their private parts with water and soap both. ${ }^{10}$ Several studies found that the poor cleaning of private parts, irregular bathing, and poor washing reusable cloth among girls were the cause of lack of separate toilet facilities in the home and school. $^{12,19}$

This study found that the majority of the rural girls used reusable cloth and only few percent used sanitary pad, and in urban majority of the girls used sanitary pad and only few percent of the girls used reusable cloth. Several studies found the similar result that majority of the urban girls used sanitary pad and only few percent of rural girls used sanitary pad. ${ }^{1,11-13,18}$ The previous study found that there were relationship between use of sanitary pad and age, monthly income, and higher mothers education of participants. ${ }^{16}$ High costs of sanitary pads were the cause of using reused cloth among rural girls. ${ }^{19}$

The participants who used reusable cloth; all of them wash cloth with water and soap both. Consistently previous study found that the majority of participants wash reusable cloth with water and soap both. ${ }^{14}$ Another study found different result that only few percent in rural and more than fifty percent of urban girls wash reusable cloth with water and soap both. ${ }^{18}$ Majority of rural girls dried their reused cloth at home in dark space that was similarly to the study. ${ }^{11}$ Only few percent in both group dried cloth under sunlight. Another study found different result that thirty three percent in rural and near fifty percent among urban girls drying reusable cloth under sunlight. ${ }^{13}$

In present study, more than fifty percent of rural girls dispose their sanitary absorbent mostly in toilet and in urban near hundred percent dispose in dustbin. Majority in both groups dispose their pads in dustbin. ${ }^{1}$ More than fifty percent rural girls and most of the urban girls change their absorbent twice or thrice daily. Another study found that less than fifty percent girls change absorbent once daily. ${ }^{12,14}$ In contrast with the another study found that the school environment including water, soap, disposal, security and privacy were the factors of frequency of changing pad. ${ }^{3,19}$ The results of present study comparable with others study that urban girls use of sanitary pad and good hygienic practices than rural girls were the reason of good washing and toilet facilities at home and school, mothers higher level of education and higher family income. . $^{3,12,19}$

\section{CONCLUSION}

This study found that menstrual hygiene practice (MHP) was more among the urban high school adolescent girls than in the rural high school adolescent girls. Significantly a greater number of girls in the urban school was using sanitary pads than the rural school girls. Mothers had been a main source of information and consultation among both groups. Unsatisfactory hygienic practices among rural girls depend on education status of mother, socio economic status, standard of living, toilet facility and water source at home and school and various other factors. The results of this study will be helpful for women's health nursing, and others health care provider to provide more emphasize on health promotion and counselling program regarding menstrual hygiene practice among rural high school adolescent girls in Bangladesh.

\section{Recommendations}

This study recommended that menstrual hygiene, health and sex education program could be conducted at rural schools and also at primary care level among adolescent girls in Bangladesh. Government and NGOs need to focus activities related to dissemination of low-cost sanitary napkin among rural girls. Health education program will be conducted for mothers to increase awareness among mothers through health personnel. Furthermore, intervention research could be developed from these findings. Further study could be conducted to find the relationship between discomforts of backache and regularity of menstruation among urban girls in Bangladesh.

\section{ACKNOWLEDGMENTS}

Authors express deep gratitude to almighty Allah, the most merciful and the most compassionate, for his mercy upon me to complete this course. Authors would like to forward his deepest and gratitude to advisor Ela Rani Shom, co-advisor Dr. Fahima Khatun and deep appreciation to our respected external Dr. Md. Shariful Islam who have provided guidance and support throughout the thesis.

Authors would like to express their gratitude to Emeritus Professor Dr. Chung Yul Lee, Prof. Seungmi Park and Prof. Tae Wha Lee for their valuable advice and guidance and validation of the research instruments. Authors want to express their deep appreciation to all of the girls who had participated in this study willingly. 
Funding: No funding sources

Conflict of interest: None declared

Ethical approval: The study was approved by the Institutional Ethics Committee IRB No: Exp.NIA-S-201813.

\section{REFERENCES}

1. Senapathi P, Kumar H. A comparative study of menstrual hygiene management among rural and urban adolescent girls in Mangaluru, Karnataka. Inter J Com Med Pub Health. 2018;5:2548-56.

2. World Health Organization. Adolescent pregnancy: Factsheet No 364. 2014. Available at: http://www. Who int/mediacentre/factsheets/fs364/en. Accessed 31 January 2020.

3. Anchebi H, Shiferaw B, Fite R, Abeya S. Practice of menstrual hygiene and associated factors among female high school students in adama town. J Women's Health Care. 2017;6(370):2167-420.

4. Santina T, Wehbe N, Ziade FM, Nehme M. Assessment of beliefs and practices relating to menstrual hygiene of adolescent girls in Lebanon. Inter J Health Sci Res. 2013;3:75-88.

5. United Nations International Children's emergency Fund (UNICEF), 2018. Menstrual Hygiene Management of Adolescent School Girls and Nuns. Available at: https://www.unicef.org/bhutan/ reports/menstrual-hygiene-management-adolescentschool-girls-and-nuns-bhutan-2018. Accessed 2018.

6. House S, Mahon T, Cavill S. Menstrual hygiene matters: a resource for improving menstrual hygiene around the world. Reprod Health Matters.2013;21:257-9.

7. International Center for Diarrheal Diseases Research, Bangladesh, 2014. Bangladesh National Hygiene Baseline Survey Preliminary Report. Available at: https://www.ircwash.org/resources/bangladeshnational-hygiene-baseline-survey-preliminary-report. Accessed June 2014.

8. Haque SE, Rahman M, Itsuko K, Mutahara M, Sakisaka K. The effect of a school-based educational intervention on menstrual health: an intervention study among adolescent girls in Bangladesh. Bangladesh Med J Open. 2014;4:e004607.

9. Das P, Baker KK, Dutta A, Swain T, Sahoo S, Das BS, et al. Menstrual hygiene practices, WASH access and the risk of urogenital infection in women from Odisha, India. Public Library Sci One. 2015;10: e0130777.

10. Sharma S, Mehra D, Kohli C, Singh MM. Menstrual hygiene practices among adolescent girls in a resettlement colony of Delhi: a cross-sectional study.
Int J Reprod Contracept Obstet Gynecol. 2017;6:1945-51.

11. Kamath R, Ghosh D, Lena A, Chandrasekaran V. A study on knowledge and practices regarding menstrual hygiene among rural and urban adolescent girls in Udupi Taluk. Manipal, India. Global J Med Public Health. 2013;2:1-9.

12. Paria B, Bhattacharyya A, Das S. A comparative study on menstrual hygiene among urban and rural adolescent girls of west Bengal. J Fam Med Primary Care. 2014;3:413.

13. Choudhary N, Gupta MK. A comparative study of perception and practices regarding menstrual hygiene among adolescent girls in urban and rural areas of Jodhpur district, Rajasthan. J Fam Med Primary Care. 2014;8:875.

14. Mokhasi VR, Mahesh V, Manjunath TL, Muninarayana C, Latha K, Ravishankar S. A comparative cross-sectional study of knowledge and practice of menstrual hygiene among adolescent girls in rural and urban schools of Rural Karnataka. Indian J Forensic Comm Med. 2016;3:163-7.

15. Alam MU, Luby SP, Halder AK, Islam K, Opel A, Shoab AK. Menstrual hygiene management among Bangladeshi adolescent schoolgirls and risk factors affecting school absence: results from a crosssectional survey. Bangladesh Med J Open. 2017;7:e015508.

16. Suhasini K, Chandra M. Factors influencing menstrual hygiene practice among late adolescent girls in an Urban Area of Belgaum. Ann Comm Health. 2017;4(4):20-4.

17. Ramathuba DU. Menstrual knowledge and practices of female adolescents in Vhembe district, Limpopo Province, South Africa. Curationis. 2015;38(1):1-6.

18. Patle R, Kubde S. Comparative study on menstrual hygiene in rural and urban adolescent. Int J Med Sci Pub Health. 2014;3:129-33.

19. Mondal BK, Ali MK, Dewan T, Tasnim T. 40 $0^{\text {th }}$ WEDC International Conference, Loughborough, United Kingdom, local action with international cooperation to improve and sustain water, sanitation and hygiene services "Practices and Effects of Menstrual Hygiene Management in Rural Bangladesh". PAPER. 2017:2578.

Cite this article as: Sultana R, Shom ER, Khatun F. Menstrual hygiene practice between rural and urban high school adolescent girls in Bangladesh. Int J Reprod Contracept Obstet Gynecol 2020;9:1039-44. 